\title{
MALEVAL, Maria do Amparo Tavares. Fernão Lopes e a Retórica Medieval. Niterói: Editora da Universidade Federal Fluminense, 2010. 254p.
}

Rafael Teixeira de Paula Lima Universidade Federal de Minas Gerais

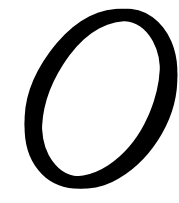

livro Fernão Lopes e a Retórica Medieval, de Maria do Amparo Tavares Maleval, é a mais nova edição da Estante Medieval, coleção que, em sua quinta publicação, já tem se tornado referência para aqueles que se interessam pelos estudos medievais, em âmbito nacional. A coleção, idealizada na Universidade Federal Fluminense (UFF) e patrocinada pela Xunta de Galicia, oferece ao leitor, agora, mais uma obra criteriosamente selecionada, na medida em que privilegia Fernão Lopes, notável figura do medievo, cronista destacado e ocupante de cargos públicos de importância e responsabilidade, além de oferecer ao leitor, do mesmo modo, a erudição da professora Tavares Maleval no tratamento do tema - tema sobre o qual a professora se debruçou em seu doutorado, defendido na Universidade de São Paulo (USP).

A coleção, que apresenta, no seu rol de autores editados, pesquisadores de referência no cenário dos Estudos Medievais nacional, como a professora Yara Frateschi Vieira, professora Andréia Cristina Lopes Frazão da Silva e professora Leila Rodrigues da Silva, traz agora a tese doutoral de Maria do 
Amparo Tavares Maleval, pesquisadora prolífica e autora de preciosa bibliografia, sempre marcada por um critério metodológico e pela clareza das idéias. Dessa vez, a atenção da professora se volta para a iminente figura de Fernão Lopes, o cronista de cargo especial e de confiança de D. Duarte, D. João I e de D. Fernando, guardião-mor dos arquivos do Estado, na Torre do Tombo. De modo especial, o que transforma essa figura em um curioso objeto de pesquisa, além da importância histórica para os estudos do período no qual se insere, é a sua maneira peculiar de interpretar e escrever aquilo que julga importante, num discurso que nega retoricamente a retórica. Atenta a isso, a professora desenvolve uma reflexão sensata e aprofundada sobre o tema.

Preparado com o mesmo cuidado editorial dos outros volumes da Estante Medieval, o livro da professora Tavares Maleval apresenta, além de um sucinto comentário do codiretor da Estante, Fernando Ozório Rodrigues, curiosas ilustrações como, por exemplo, uma cópia apógrafa, que remonta às primeiras décadas do século XVI; um documento autógrafo, reproduzido por Anselmo Braamcamp, em sua edição da Crônica de D. João I; e o célebre Painel do Arcebispo, provavelmente de Nuno Gonçalves, no qual Fernão Lopes estaria, supostamente, retratado. Somado aos elementos imagéticos, o leitor interessado encontrará rigor metodológico e fluidez expositiva, fazendo com que a leitura se torne, acima de tudo, prazerosa.

A configuração do livro da professora Tavares Maleval oferece aos leitores um percurso guiado, de modo a favorecer a compreensão daqueles que buscam se aprofundar sobre $o$ tema proposto. Habilmente, a professora sistematiza suas informações em blocos coerentemente dispostos. O primeiro deles é uma rica contextualização sobre Fernão Lopes, o cronista notável que, certamente, viveu em uma das épocas mais 
conturbadas da história de Portugal, tendo atravessado mais de três reinados em seu período de atividades. A pesquisadora trabalha elementos da vida de Fernão Lopes, assim como do contexto no qual estava inserido, com eficácia, e no momento em que aborda as fontes historiográficas, deixa explícita a precisão filológica com que se engaja no trabalho.

Em um segundo momento, a professora se volta para a retórica medieval, onde vence o desafio de tratar de um objeto tão extenso, sem perda da acuidade e profundidade. O leitor observará um tratamento seguro e fundamentado desde a origem e sistematização da retórica chamada "antiga", até a influência do cristianismo na retórica, com um adendo à tese da professora, de 1982: uma súmula da história da ars praedicandi, ou seja, a retórica da pregação. No que diz respeito aos fundamentos sobre os quais a professora Tavares Maleval trabalha, nota-se a mesma firmeza filológica, na medida em que discute a concepção de retórica enquanto uma das principais disciplinas do Trivium, das Artes Liberais, assim como uma análise fundamentada em Aristóteles - através da divulgação de Cícero, Santo Agostinho e Isidoro de Sevilha, concepções sem as quais qualquer estudo poderia ser considerado inepto.

A retórica da Crônica de D. João I - parte primeira é, então, o momento no qual a pesquisadora faz a junção de todas as suas considerações, direcionando-as ao seu propósito. O trabalho é sistemático e desenvolvido, simultaneamente, sobre a utilização de recursos retóricos por parte de Fernão Lopes, observados por meio de um prisma discursivo; e sobre as implicações das retóricas clássica e medieval, que a professora Tavares Maleval comenta com propriedade. Tal articulação contribui para fundamentar a defesa de que o cronista português teria, sim, feito uso de retórica para justificar a ascensão da Dinastia de Avis (1383-1385). 
Fecha o livro um conjunto exaustivo de referências bibliográficas, atualizadas e organizadas de acordo com o interesse daquele que tente aprofundar-se nas questões levantadas pela obra da eminente pesquisadora. Publicada em 1982, a tese de doutoramento da professora Tavares Maleval, ampliada e editada pela Universidade Federal Fluminense (UFF), se apresenta como um notável trabalho para aqueles que se debruçam sobre as crônicas de Fernão Lopes, ou sobre a retórica medieval e, devido a sua versatilidade, é útil tanto àqueles que se encontram no começo de suas pesquisas, quanto aos que já têm conhecimento sobre o tema. Por se tratar de um livro erudito e agradável, de uma perspicácia analítica notável, torna-se mais que justificada a seleção de Fernão Lopes e a Retórica Medieval, da professora Maria do Amparo Tavares Maleval, para a Coleção Estante Medieval. A leitura é indispensável aos pesquisadores que se interessam pelo medievo, não só na área das Letras, mas também da História e da Filosofia. 